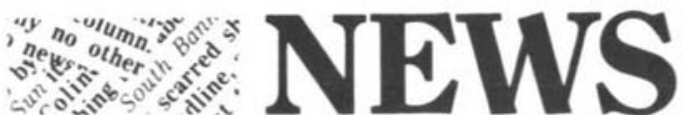

Taxing reading

In the European Community, the question of whether VAT (Value Added Tax) should be applied to books is becoming a serious issue. In the first 1988 number of the International Publishers Bulletin, the editor, J. Alexis Koutchoumow, has devoted his editorial to the subject, under the heading 'Don't tax reading!'. The remarks that follow come from that editorial:

'At first sight, the taxing of books as an ordinary product may seem an enterprising venture, but in fact it would be very wrong. Not because the book trade is incapable of . coping with the laws of the market place ...., but rather because the position the book occupies in society is unique. Just as the author's work, once written, somehow escapes from its creator, the book once

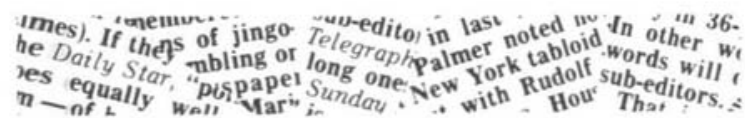
published escapes from the hands of its publisher.

'Whether the diehards of marketing and management like it or not, the book is still the foremost instrument in transmitting knowledge from one generation to the next, in the creation of new jobs through ongoing instruction 3 in the accumulation and use of knowledge and expertise and also in creating social identity for both individuals and groups of people .... The marketplace has never looked on books as mere commodities. The consumer knows from school age onwards that cultural, economic and social promotion derives from education via books. The intrinsic value of the Book cannot be commensurate by its commercial value and retail price. The IPA cannot agree to the taxation of books at any given rate, be it $23 \%$ or $2 \%$, without wide and public debates on the importance of the Book in Society.'

\title{
Acid test
}

If books are as important to civilization as Koutchoumow claims, do the publishers for whom he speaks take enough care of them?

This question relates not to storage but to the very stuff that books are made of. The issue here is the kind of paper that should be used, so that the books of our time - taxed or untaxed - can survive for a remoter posterity to read. In the normal course of events many will perish rather casually; a more serious matter is those gathered in libraries with the express intention of keeping them safe for centuries.

The offender is acid. Writing in The Listener (7 Jan 88), Michael Delahaye notes that 'we're not making paper like we used to. In fact, we haven't been making it in the old way since the $1850 \mathrm{~s}$, when the rags ran out and the papermakers turned to mechanically ground woodpulp to satisfy the demands of the reading masses and the voracious appetites of the new steam printing-presses.' However, lignin in the wood pulp and chemicals added to 'size' the finished product (making it less absorbent) both contribute to the

discoloration and disintegration of pages, in a slow acidulous burnout.

Most modern books are in fact more in need of preservation than centuries-old manuscripts and incunabula. Of the British Library's collection of books produced after 1850 , up to two million are at risk, and that number is added to every day as publishers turn out more and more acid-rich volumes.

Whatever the solution to that horrific problem, there is something that can be done about adding to the pile of endangered texts: printing on acid-free paper, a commodity that is widely available. It is, however, more expensive than conventional paper, although the gap could be narrowed if more of it were used. In the United States, a National Standard has been introduced for 'permanent paper', to focus attention on the problem. 'As a result,' reports Delahaye, 'a third of the books published there are now acid-free'. In Britain, however, a 'guesstimate' suggests that $90 \%$ of books and periodicals 'are still printed on the old, self-destructing acid paper. As for an American-style Permanent Paper Standard, it hasn't even been formulated, let alone introduced. 